\title{
Guns and Goddams: was there a Military Revolution in Lancastrian Normandy 1415-50? ${ }^{1}$
}

\author{
Anne Curry
}

Historians like labels and categories. In part this has been driven by the needs of pedagogy. It cannot be a coincidence that an early use of the term "La Guerre de Cent Ans" was in Chrysanthe-Ovide Desmichels' Tableau Chronologique de l'Histoire du Moyen Age published in 1823. This work was symptomatic of the expansion of schooling in early nineteenth-century France in which competitive examinations stimulated publication of aides-mémoire. ${ }^{2}$ Other nations followed suit. Even in the 1970s teachers in Britain were still using William Edwards' Notes on British History and Notes on European History, cribs published almost a century earlier, which crammed the heads of unsuspecting students with "the so-and-so system," "the age of whatsit," and "the thingummy "revolution" so that it could all be spewed out again in the examination room.

Such labels and categories can be valuable communication tools. They also give shape to our research and facilitate comparison and debate. But they can operate as straightjackets and encourage tunnel vision. Take the expression "Hundred Years War." At one level it is useful because it emphasizes the insoluble nature of Anglo-French conflict once an English king had claimed to be the rightful king of France. Yet it is also misleading since it gives the wars fought between the 1330s and 1450s an artificial unity, a problem which links to the topic of this essay. Then there is the expression, "the military revolution." The historiography is now so well established that it would be otiose to spend time going through it. ${ }^{3}$ Yet the military revolution has been a moveable feast. Cynically speaking, it is to be found in the period in which the particular author considers him or herself to be expert. There is an element of "seek and ye shall

1 This paper was first delivered as the Journal of Medieval Military History Lecture at the International Medieval Congress, Kalamazoo, in May 2008.

2 The first book to bear the title La Guerre de Cent Ans was published by Jean-Louis-Théodore Bachelet in Rouen in 1852. For broader discussion see Anne Curry, "France and the Hundred Years War, 1337-1453," in France in the Later Middle Ages, ed. D. Potter (Oxford, 2003), pp. 90-93.

3 The Military Revolution Debate: Readings on the Military Transformation of Early Modern Europe, ed. Clifford J. Rogers (Boulder, 1995). Note also Clifford J. Rogers, "The Idea of Military Revolutions in Eighteenth and Nineteenth Century Texts," Revista de História das Ideias 30 (2009), 395-415. 
find" about it, in much the same way as "the rise of the gentry" or "the rise of the state" is found wherever a period specialist is looking.

The reason is that we have tended to define "the military revolution" in any way we wish. Therefore it can be whenever we want it to be. And we all desperately want it to be in our period. After all, it is not $a$ military revolution, but the military revolution. Or for Clifford J. Rogers, in his highly important article of 1993, military revolutions - the infantry revolution of the fourteenth century, and the artillery revolution of the fifteenth. ${ }^{4}$ In his article, Lancastrian Normandy - signifying the English occupation of the duchy by the English from Henry V's renewal of war in 1415 to the expulsion by the French in 1450 - features in both revolutions. In the infantry revolution it is by emphasis on the English archers, and also the archer/dismounted man-at-arms combination, at the battles of Agincourt (1415) and Verneuil (1424). In the artillery revolution it features in the use of guns by Henry V at the siege of Harfleur in 1415 (although Rogers argues that the "intention was ... to silence the guns and catapults with which the defenders harassed his army") and at Rouen and other sieges in the second campaign (1417-19). Rogers sees a turning point in the mid 1420s when garrisons began to surrender "because the besiegers' guns have rendered their position indefensible." Here he features particularly the conquest of Maine (which, I would add, was made possible by the victory at Verneuil since that battle enabled the garrisons in Normandy to be reduced in size and diverted to the campaign southwards) and the power of the French gunpowder artillery in the reconquest of Normandy in 1449-50. His conclusion is that "a revolution occurred in the art of war around the 1420 s to 1430 s, as gunpowder artillery overturned the centuries-old dominance of the defensive in siege warfare." ${ }^{5}$

Agincourt apart, the fifteenth-century phase of the war has not excited as much interest in Hundred Years War studies as the fourteenth century. The problem may be one of the accessibility of sources. English chronicling in the fifteenth century is thin save for the Latin narratives of the reign of Henry V. ${ }^{6}$ There are few chronicles produced within Normandy itself, although the narratives of the French reconquest of 1449-50 are more rewarding. ${ }^{7}$ In other words, we have accounts of the conquest of Normandy by the English and the loss of Normandy to the French, but little in between. Lancastrian Normandy (more properly, Lancastrian France since the English held other areas of northern France - Paris and the hinterland to the east from 1420 to 1435, and Maine

4 Clifford J. Rogers, "The Military Revolutions of the Hundred Years War," Journal of Military History 57 (1993), 241-78.

5 Ibid., p. 266.

6 Antonia Gransden, Historical Writing in England II, c. 1307 to the Early Sixteenth Century (London, 1982).

7 Narratives of the Expulsion of the English from Normandy MCCCCXLIX-MCCCCL, ed. J. Stevenson (London, 1863); Chronique de Charles VII roi de France par Jean Chartier, ed. Vallet de Viriville, 3 vols. (Paris, 1858). The handful of works covering the interim include Chronique normande de Pierre Cochon, ed. Charles de Robillard de Beaurepaire (Rouen, 1870), and Croniques de Normendie (1223-1453), ed. Amédée Hellot (Rouen, 1881). 
from the mid 1420 s to its surrender in 1448) can claim to be a "missing link" in studies of the medieval military revolution. ${ }^{8}$ In the 1410s it appears to be the English who carried the torch in both infantry and artillery developments with their archers and their bombardments of fortifications, yet by 1449-50 it was the French who did so, with their francs archers and their use of field as well as siege artillery in the expulsion of the English. ${ }^{9}$ The question arises therefore - what happened in between?

We may not have many chronicles for Lancastrian Normandy but we have exceptionally abundant financial records for military administration on both sides of the Channel. ${ }^{10}$ Expeditionary armies, sent almost annually from England, were raised through the indenture system. Even where we do not have surviving indentures, we can know the leadership, size, composition, and other conditions of service, through the payments recorded in the Issue Rolls. This information is virtually complete for the whole period and for some armies we also have details of soldiers' names through muster rolls. For the first conquest made in France - Harfleur - we have muster rolls but more importantly the account book of its treasurer. Although Henry began his second campaign using English administrative procedures, his success soon enabled him to take over French structures, and from his death, all of his conquests were absorbed within the French financial system of the chambre des comptes based at Paris and, when the French capital was recovered by Charles VII in 1436, at Rouen. ${ }^{11}$ This archive is huge, enabling us to reconstruct the garrison establishment of around forty-five manned places in Normandy as well as the field activities which were conducted, and which combined detachments from the garrisons with troops raised by other means within English-held areas and also with expeditionary armies from England. Again we have many muster rolls, enabling us to probe deeply into the patterns of service of the soldiers themselves. All of this material

8 Christopher T. Allmand, Lancastrian Normandy 1415-1450. The History of a Medieval Occupation (Oxford, 1983); G. L. Thompson, Paris and its People under English Rule: The AngloBurgundian Regime 1420-1436 (Oxford, 1991); A-M. Bouly de Lesdin, "Le Vexin français sous la domination anglaise (1419-1449)," Mémoires de la société historique et archéologique de Pontoise, du Val-d'Oise et du Vexin 62 (1969). As yet, there is no comprehensive study of Maine under English rule but useful is Robert Charles, "L'invasion anglaise dans le Maine de 1417 à 1428," Revue historique et archéologique du Maine 25 (1889).

9 Philippe Contamine, Guerre, état et société à la fin du moyen âge. Études sur les armées des rois de France 1337-1494 (Paris, 1972), chap. 10; idem, "L'artillerie royale française à la veille des guerres d'Italie," Annales de Bretagne 71 (1964).

10 Anne Curry, "English Armies in the Fifteenth Century," in Arms, Armies and Fortifications in the Hundred Years War, ed. Anne Curry and Michael Hughes (Woodbridge, 1994), pp. 39-68.

11 Anne Curry, "L'administration financière de la Normandie anglaise: continuité ou changement," La France des principautés. Les chambres des comptes xive et xve siècles (Paris, 1996), pp. 83-103; eadem, "Harfleur et les Anglais, 1415-1422," in La Normandie et l'Angleterre au moyen âge, ed. Véronique Gazeau (Paris, 2003), pp. 173-87. 
is being fed into a database project to list all known soldiers in the service of the English crown between 1369 and 1453. ${ }^{12}$

These administrative sources are crucial to our evaluation of both the "software" (i.e. the soldiers) and the "hardware" of any prospective military revolution. On the latter they record purchase, repair and movement of guns as well as providing much on fortifications, and indeed on so many aspects of military activity. Furthermore, they enable a much greater degree of granularity, and in particular a much clearer impression of change over time, than do the chronicles. The purpose of this essay, therefore, is to make some general observations, first on the infantry revolution and secondly on the artillery revolution as it applies to Lancastrian Normandy, and then to reflect on what this suggests about "the military revolution."

\section{Lancastrian Normandy and the Infantry Revolution}

First, then, the software - the "goddams," the nickname applied to English soldiers by those in their French conquests on account of their propensity for swearing. Do the English armies of the period (expeditionary, garrison, and field) constitute a military revolution? How do they compare with the fourteenthcentury armies which Rogers considers evidence of the infantry revolution? At first sight, the answer looks simple. From the first invasion of 1415 to the loss of the duchy, the most commonly found ratio is one man-at-arms to three archers. That conclusion applies equally to all kinds of armies. It is seen in expeditionary armies both in terms of totals and within individual retinues (Table 1). It also applied in the garrisons in the conquered territories. For instance, the garrison at Harfleur initially held 300 men-at-arms and 900 archers. In the year 1422-23 it contained $40+120$, but after the victory at Verneuil in August 1424 it was reduced to $15+45$. In $1433-34$ it held $30+90$, and in the 1440 s $50+150 .{ }^{13}$ Similarly, the escorts of the commanders in France were commonly 20 men-atarms and 60 archers, ${ }^{14}$ and when field armies were put together from time to time from garrison detachments and other retinues, they also usually had three times as many archers as men-at-arms. ${ }^{15}$ The ratio of 1:3 was the intended and the expected norm. This is revealed by the fact that on some occasions, espe-

12 This project, based at the Universities of Reading and Southampton, is funded by the Arts and Humanities Research Council, and can be found at www.medievalsoldier.org.

13 Bibliothèque Nationale de France [hereafter BNF], manuscrit français 4485, pp. 213-15; Letters and Papers Illustrative of the Wars of the English in France during the Reign of Henry the Sixth, King of England, 2 vols. in 3 (London, 1861-64), vol. 2, part ii, pp. 540-46; BNF manuscrit français 26274/10.

14 For one example, see Anthony J. Pollard, John Talbot and the War in France 1427-1453 (London, 1983), pp. 69-70.

15 Anne Curry, "The Organisation of Field Armies in Lancastrian Normandy," in Armies, Chivalry and Warfare in Medieval Britain and France, ed. M. Strickland (Stamford, 1998), pp. 207-31. 
cially in the raising of field armies, only the number of men-at-arms was given followed by the expression "et les archers," or "et les archers à l'afferant." 16 Since we can know from the sources what the number of archers raised was, we can see that it was indeed three times the number of men-at-arms.

Table 1. Some examples of expeditionary armies, 1423-1431 (information taken from the Exchequer Issue Rolls, The National Archives E 403)

\begin{tabular}{lcc}
\hline Date & Men-at-arms (mounted) & Archers (mounted) \\
\hline 1423 & 380 & 1140 \\
1424 & 411 & 1230 \\
1425 & 349 & 1047 \\
1427 & 300 & 300 \\
1430 & 1196 & 3596 \\
1431 & 200 & 600 \\
\hline
\end{tabular}

In making comparison with the fourteenth century, we can see therefore that the infantry revolution was by no means linear but rather fluctuated across the period of the Hundred Years War. In the expeditionary armies of the early years of the war, taking the other kinds of troops, in addition to archers, as infantry, the ratio was between 1:1.6 and 1:2 (Table 2) ${ }^{17}$ In the second phase from 1369 to 1389 , it was commonly $1: 1$ with a range up to $1: 1.6$ (Table 2). ${ }^{18}$ In addition, there was a trend towards simplification. From 1369 onwards to the end of the Hundred Years War, troops for the expeditions to France were recruited in two categories, men-at-arms and archers, and almost all were mounted. Commanders and captains always mustered as men-at-arms and are counted in the numbers. In terms of ratios, therefore, the exceptions of the Crécy campaign of 1346, at 1:5, and the Reims campaign of 1359, at 1:2.5, are notable. Save for these exceptions, however, the fifteenth-century expeditions contained proportionately more infantry than those of the fourteenth.

16 For instance, in reference to the troops ordered for the conquest of Maine between December 1424 and February 1425 (BNF manuscrit français 4491, fol. 26v).

17 These figures are derived from a number of studies, including Albert E. Prince, "The Strength of English Armies in the Reign of Edward III," English Historical Review 46 (1931); Michael Prestwich, "English Armies in the Early Stages of the Hundred Years War," Bulletin of the Institute of Historical Research 56 (1983); Andrew Ayton, "English Armies in the Fourteenth Century," in Arms, Armies and Fortifications, ed. Anne Curry and Michael Hughes; Cifford J. Rogers, War Cruel and Sharp: English Strategy under Edward III 1327-1360 (Woodbridge, 2000); Andrew Ayton and Philip Preston, The Battle of Crécy (Woodbridge, 2005).

18 James Sherborne, "Indentured Retinues and English Expeditions to France, 1369-1380," English Historical Review 79 (1964), 718-46; Adrian R. Bell, War and the Soldier in the Fourteenth Century (Woodbridge, 2004), pp. 10-11, 56-57. 
Table 2. Examples of fourteenth-century expeditionary armies

\begin{tabular}{llccc}
\hline & Ratio & Men-at-arms & Mounted archers & Other infantry \\
\hline 1339 & $1: 1.6$ & 1800 & 1100 & 1700 \\
1340 & $1: 2$ & 1300 & 1000 & 1600 \\
1342 & $1: 2$ & 1800 & 1800 & 1700 \\
1346 & $1: 5$ & 2800 & 2800 & 8000 \\
1355 & $1: 1.6$ & 1000 & 1000 & 600 \\
1359 & $1: 2.5$ & 3000 & 3000 & 4000 \\
1369 & $1: 1.6$ & 1200 & 2200 & 400 \\
1370 & $1: 1$ & 2000 & 2000 & \\
1373 & $1: 0.9$ & 3032 & 2893 & \\
1379 & $1: 1$ & 2000 & 2000 & \\
1387 & $1: 1.3$ & 1107 & 1390 & \\
\hline
\end{tabular}

Why precisely the 1:3 ratio developed needs further research, as does the whole issue of whether numbers in individual retinues were set by the crown or by the captain who recruited them. ${ }^{19}$ Its first use for an expedition to France was in 1412 (under Thomas duke of Clarence) but it is seen from at least 1406 in English armies sent to subdue the Glyndŵr rising in Wales. ${ }^{20}$ Since the future Henry $\mathrm{V}$ was in command, it is tempting to link him to the devising of the 1:3 ratio, and it is certainly a ratio which dominated military organisation in his French campaigns.

Rogers has suggested that structures were moulded by the various military actions anticipated. Arguably, therefore, the 1:1 ratio of the late fourteenth century was deemed appropriate for chevauchée-style campaigns. Interestingly, at the same time that the 1:3 ratio became the norm for land campaigns, a ratio of one man-at-arms to two archers was preferred for naval activity (as in 1416), ${ }^{21}$ presumably because for naval warfare opportunities for arrow shot were more limited and most fighting was hand to hand. Rogers' argument on the infantry revolution in his 1993 article focuses on battle situations. Is the development of the 1:3 ratio linked to anticipation of set-piece battles? Its use in the particular circumstances of Wales would not support this interpretation since the army

19 For discussion on this point relating to 1415, see Anne Curry, Agincourt: A New History (Stroud, 2005), pp. 57-58.

20 John D. Milner, "The English Enterprise in France, 1412-13," in Trade, Devotion and Governance. Papers in Later Medieval History, ed. Dorothy J. Clayton, Richard G. Davies and Peter McNiven (Stroud, 1994), pp. 80-101. In April 1406 Prince Henry entered into indentures as royal lieutenant in Wales with 500 men-at-arms and 1,500 archers (Calendar of Patent Rolls 1405-1408, p. 215). We also know that the prince was assigned $120+360$ additional troops (The National Archives, London [hereafter TNA], E 404/21/310).

21 Anne Curry, "After Agincourt, What Next? Henry V and the Campaign of 1416," The Fifteenth Century 7 (2007), 23-51. 
of 1406 was intended largely to enable Prince Henry to establish garrisons. It is dubious whether battle was in mind in the 1412 expedition. Most of the expeditionary armies raised in the reigns of Henry V and VI were explicitly for conquest of places and territory. Indeed, it is important to remember that they provided garrisons for the places captured (as in the case of Harfleur in 1415 where, as we have seen, a garrison of 1:3 was installed). For Henry V's first campaign, however, it is significant that additional archer companies totalling 1650 men were raised from Lancashire, Cheshire and South Wales, taking the proportion of bowmen higher. ${ }^{22}$ Even if Henry's march from Harfleur to Calais was undertaken in the hope of avoiding battle, it is difficult to deny that at the point he had raised his army, he had reckoned the French might attempt to meet him the field, and that a large number of archers would be useful, as they had been at the engagements of the fourteenth century. This was less of a concern in later campaigns, although Henry was astute enough to realise that different troops might suit different purposes, as when, during the siege of Rouen, he had a company of lightly armed and mounted Irish sent to Normandy to act effectively as cattle rustlers to stop food reaching the French but to take it instead for the English army. ${ }^{23}$

Military considerations surely played a role in establishing the 1:3 ratio, but none the less we need to see it in other contexts. The first was the perennial problem for English kings in their campaigns in France - their shortage of menat-arms in comparison to their enemy. In the early campaigns Edward III sought to remedy this by using mercenary troops provided by his continental allies. In order to launch his great campaign of 1346 (if 14,000 strong, then the largest army ever sent to France), he had to make a huge effort to raise men-at-arms (about 2,800) as well as other kinds of troops. A similar effort is seen in 1415 in order to exceed 2,000 men-at-arms and to produce an army of around 12,000 men. Later in the reign Henry commissioned enquiries in the shires of England to try to find esquires who would be suitable for service in France and who had not yet served. ${ }^{24}$ The database project will help us understand the size and nature of the military elite in England, and also why there was such a dramatic decline of knights in the fifteenth century. We can already conclude that in order to raise large armies to make an impact in France (such as Henry intended in 1415, and as Edward had intended in 1346 and 1359), the only possibility was to raise larger proportions of archers.

Save for the expeditions of 1415 and 1417, English armies sent to France under Henry V and VI were generally smaller than those of the fourteenth century. The largest after these was the army of just under 5,000 which crossed

22 Curry, Agincourt, pp. 60-61.

23 James H. Wylie and William T. Waugh, The Reign of Henry the Fifth, 3 vols. (Cambridge, 1914-29), 3:131-32.

24 Anthony E. Goodman, "Reponses to Requests in Yorkshire for Military Service under Henry V," Northern History 17 (1981). 
with Henry VI in 1430 on the coronation campaign. ${ }^{25}$ But what we must not forget is the intensity of effort, which was much greater than in the preceding century. Expeditionary armies were sent every year until the truce of 1444, and often more than one per annum. The sustaining of this effort has implications for the composition of armies and for the infantry revolution. An intended ratio of 1:3 remained in place throughout the first half of the fifteenth century for armies raised in England for service in northern France but proved increasingly difficult to achieve. The first "chink" in the armor shows in the army raised by the earl of Salisbury in the summer of 1428 and which ended up at the siege of Orleans in the autumn. This was supposed to contain 600 men-at-arms and 1800 archers, but the earl could find only 444 men-at-arms and so compensated, as his indenture permitted him to do, by raising more archers $(2,250$ at the finish), so that the ratio moved to $1: 5 .{ }^{26}$ There are examples of similarly intentional higher ratios in the years which followed. Indeed, many expeditions after 1428 followed a 1:4 ratio, such as that sent under the earl of Arundel in the summer of 1434 (234 men-at-arms and 934 archers). Some went even higher on purpose, with 1:20 in a force sent under John Beaufort in February 1440, 1:11.5 in the army taken by John Talbot, earl of Shrewsbury, in 1442 with the hope of recovering Dieppe, and 1:8.8 in the force sent in March 1450. But in other cases the ratio was higher than intended. The army sent under John Beaufort in 1443 , for instance, ended up with 6.6 archers to every man-at-arms instead of the intended 4.25.

Where the ratio was set deliberately high, we can suggest a financial imperative since archers had a daily wage of half of that of the men-at-arms (6d. as opposed to one shilling). Henry $\mathrm{V}$ had been able to raise massive and regular taxation to support his armies at the 1:3 ratio. The government of the early years of the minority kept this up since the relatively strong position of the English in France required the sending of relatively small, although regular, armies. The crisis of 1429 changed this situation, requiring more troops to be sent more frequently. This was not popular in England. It is not surprising that in August 1429 there should have been a request that those who had been granted lands in Normandy should return there to defend them. ${ }^{27}$ Remember too that these land grants often included a requirement to provide troops for the royal host - intriguingly the ratio set by Henry $\mathrm{V}$ for this had been 1:2, perhaps more reflective of the situation in the duchy where there was a relative lack of archers in comparison to England. ${ }^{28}$ Taxation was hard to prise out of the commons in

25 Anne Curry, "The 'Coronation Expedition' and Henry VI's Court in France, 1430-32," in The Lancastrian Court, ed. Jenny Stratford (Stamford, 2003), pp. 30-54.

26 Curry, "English Armies," p. 46. The following discussion is based on detailed study of the financing of expeditionary armies, as evidenced in the Issue Rolls (TNA E 403).

27 Proceedings and Ordinances of the Privy Council of England 1386-1542 [hereafter PPC], ed. Harris Nicolas, 7 vols. (London, 1834-37), 3:349.

28 Anne Curry, "Le service féodal en Normandie pendant l'occupation anglaise, 1417-50," in La France anglaise au moyen âge, ed. Philippe Contamine (Paris, 1988), pp. 233-57. 
the 1430s and 40s. It is also striking, as the years passed, how few members of parliament had experience of service in France. This phenomenon ties in with other indications of an increasing divide between the English in France and the English in Normandy especially after the king's coming of age and his own lack of interest in overseas interests. It was proving increasingly difficult to persuade the military elite to serve, as revealed not only by the declining participation of the nobility, knights and gentry but also the planned and unplanned fall in the proportion of men-at-arms in the expeditionary armies. At the moment of crisis in 1449-50 it even proved impossible to recruit the right number of archers. For the army of March 1450, the last real attempt to relieve the English position in the face of Charles VII's reconquest, recruitment of men-at-arms fell 60 short, and of archers 400 short. $^{29}$

Some conclusions can therefore be suggested. The first is that the composition and size of armies was much affected by political will and financial resources. Henry V had been able to sustain his military effort; his successors could not do so. The second is that if there was an English infantry revolution, it was more sustained in the fifteenth century than the fourteenth. This has been shown to be true for the expeditionary armies. A few additional comments need to be made for the garrisons and other troops within Normandy. Whilst maintaining an overall ratio of 1:3, the garrisons increasingly had their men-at-arms in two groups: mounted and foot. In reality, therefore, the proportion of infantry in the duchy was greater than $75 \%$. In the example of Harfleur, for instance, in 1422 the 40 men-at-arms were composed of 16 mounted men-at-arms and 24 foot. In 1424 , the 15 men-at-arms were six mounted and nine foot. The 50 of the $1440 \mathrm{~s}$ were between two and eight mounted with the rest unmounted. Commonly the composition of archers in the garrisons followed the same patterns. It is easy to understand why foot men-at-arms and archers should have been deemed adequate for garrison defence, especially where places were not deemed to be in much danger. The largest proportions of foot therefore tend to be found well away from the frontiers. Indeed, on the frontiers garrisons were either fully mounted, or else they had an ordinary garrison with a mixture of foot and mounted, and a mounted patrol of men-at-arms and archers specifically said to be "pour les champs." 30

There was therefore flexibility and response to particular circumstances. This can be seen in other ways. For instance, it was common for the baillis and other administrative officials in Lancastrian Normandy to have retinues composed almost exclusively of mounted archers. The master of the ordnance commonly had a retinue of 14 mounted archers, but this could be boosted when a larger protective force was needed. ${ }^{31}$ Archers were clearly seen as extremely useful

29 Curry, "English Armies," p. 47.

30 Reforms of the duke of Bedford in October 1434 put this on a regular footing, as the garrison indentures show (BNF manuscrit français 26058/2370-2385).

31 Christopher T. Allmand, "L'artillerie de l'armée anglaise et son organisation à l'époque de Jeanne d'Arc," in Jeanne d'Arc. Une Époque, un rayonnement (Paris, 1982), pp. 76-77. 
and adaptable. This is not surprising, since they were required to be armed with swords and daggers as well as their archery equipment. Although with less in the way of protective armor, in battle situations they could be involved in hand to hand fighting: at Agincourt, for instance, they came in with hammers and knives to finish off the French man-at-arms. The fact that so many were mounted enabled them to participate in raids, patrols and skirmishes, moving as quickly as their men-at-arms. Contingents sent out against brigands or for other policing actions were regularly made up of mixed retinues of men-at-arms and archers, as were the garrison detachments sent to sieges. Even if the mounted archers were not expected to fight from horseback, they performed some of the other functions of a mounted force: fast movement, harassment, pursuit.

We must remember too that in Lancastrian Normandy much military action was policing a civilian population, collecting victuals, maintaining a controlling and defending presence. In this respect infantry was just as useful as cavalry, archers as men-at-arms. At sieges it often proved difficult to maintain large numbers of horses because of shortage of victuals (as is well known, feeding a besieging army was as difficult as feeding one within a besieged place.) This caused a further blurring. On raids and in sorties from siege camps, much activity was in the form of skirmishing where battle-type positions would not be drawn up in advance with a delay before engagement. Whilst mounted men-at-arms would be essential for true cavalry charges against similar troops (for instance, when cavalry made a sortie from a besieged town), these engagements were few and far between. We can note here the actions of soldiers from the coastal garrisons who also patrolled the sea. To cite only one example: three foot men-at-arms and 53 archers of the garrison of Harfleur were in a boat capturing ships off the coast and sailing up to Calais to sell their booty from 1 November to 22 December 1441, but returning to their home garrison in time for Christmas. ${ }^{32}$

What we see most of all in Lancastrian Normandy is how men-at-arms and archers were integrated. They regularly operated in tandem in the mixed retinue, which also formed the basis of recruitment. Those mustering as mounted menat-arms no doubt had more and better horses (trained for combat situations the difference therefore is in the schooling of the horse) and superior personal arms. It was from their ranks that the commanders of units, captains, lieutenants, constables, marshals, chefs des montres came - a list which reflects the different levels of command needed in an army, especially one of occupation. Men-at-arms were commonly placed in command of groups of archers (in some muster rolls the archers are placed under a man-at-arms as their maitre, often in the 1:3 ratio), and mounted men-at-arms are often seen in command of foot men-at-arms as well as archers. The distinction between the various kinds of troops is therefore as much one of social status as military function. Only men from a certain social status trained from their youth with the lance, whether for use on horseback or on foot. Only they participated in that upper class sport, 
the tournament. There may also be an age element here, with young men of status beginning their careers as archers. An occupation which lasted for thirtyfive years was bound to have a major impact on soldiering as a career, stimulating the rise of professionalism for soldiers of all kinds, and also affecting patterns and trends in command (not least as the participation of the highest echelons diminished in the reign of Henry VI). It is perhaps this which is the real contribution of the period to a military revolution, especially for the infantry. However, there is emerging evidence from our database that from 1429 onwards, a good number of the archers of the garrisons, and even some of the men-atarms, were not English at all but were locally recruited. If there was an infantry revolution in Lancastrian Normandy, we must ask whose it was - the English or the French - and also how it may link to the reforms which Charles VII made to his army in the mid 1440s which contributed to his success in the Reconquest of 1449-50. This issue will be returned to in the conclusion, but now let us turn to the second element in Rogers' medieval military revolution - the question of gunpowder artillery.

\section{Lancastrian Normandy and the Artillery Revolution}

The use of gunpowder artillery by the English predates the conquest of Normandy. Henry V as prince certainly used sizeable pieces in the Welsh wars, most notably in the siege of Aberystwyth in 1407 where there is reference to a piece weighing over 4,000 pounds, over ten times the weight of the majority of cannon in royal hands in $1382 .{ }^{33}$ Was it this experience which encouraged Henry to a siege-based strategy in his invasions of Normandy? We know that he took gunpowder artillery with him in 1415. The bombardment of Harfleur is emphasised in the Gesta Henrici Quinti. Although to date I have not been able to find administrative sources which tell us more about the artillery pieces themselves, we do know the names of the gunners he took, and that they did not accompany him on his march northwards, the implication being that neither did the guns, which were left in Harfleur for the defence of the place. During the siege of Rouen the king ordered that the guns at Harfleur should be brought up the river to the siege. Yet there is little evidence of much bombardment either at Rouen or at earlier sieges of the second campaign. ${ }^{34}$ Henry had learned an expensive lesson at the siege of Harfleur, that excessive damage to the fortifications of a place which then fell to him could make its defence expensive and problematic. Large sums had to be spent on the rebuilding of Harfleur's defences in the 1420 s.

33 Michael Prestwich, Armies and Warfare, p. 293.

34 Anne Curry, "Henry V's Conquest of Normandy 1417-1419: The Siege of Rouen in Context," Guerra y diplomacia en la Europa Occidental 1280-1480. XXXI Semana de Estudios Medievales. Estella 19-23 de julio 2004 (Pamplona, 2005), pp. 237-54. 
We can trace the provision of gunpowder artillery for other expeditionary armies, most notably that of the earl of Salisbury in 1428 which was intended as a major push towards the Loire and beyond. ${ }^{35}$ There is therefore some irony that the earl was the most famous victim of gunshot at the siege of Orleans. In addition to what was brought over from England, however, we must not overlook two other forms of supply. When the English captured places in France, they also captured the defensive and offensive weaponry within them, and compositions for surrender required that there should be no damage to material de guerre by those evacuating the place. Secondly, once in control, the English could commission the construction of artillery pieces. In theory therefore there is no reason to suppose the English lacked means of provision. The financial records of Lancastrian Normandy are not lacking in references to castles, towns and other fortifications housing guns, powder and other necessaries. At Pont de l'Arche in 1423, for instance, there was a gros canon "en la basse court dudit chastel aupres de l'entrée de la porte." ${ }^{36}$ We can also trace cannoniers present in such places, as well as administrators responsible: take for example Jean Holland "garde des canons, artillerie et habillemens de guerre de monsieur le roy" in the town of Harfleur in September 1427, where he also held the office of grenetier. ${ }^{37}$ Purchases of the ingredients for gunpowder are also evidenced..$^{38}$

Christopher Allmand has already alerted us to the masters of ordnance and artillery, and their retinues. ${ }^{39}$ The financial records also demonstrate how the masters were commonly given a sum of money to spend at the outset of a campaign or action, in addition to their regular annual payment. During the siege of Mont-Saint-Michel in 1426, Lord Scales as captain of one of the bastides built for the blockade by land was provided by the master of ordnance with seven "wuglaires" and three "menus bombardes" as well as powder. In June 1431 twenty cartloads of cannon, ribaudequins and culverins were taken to the siege of Louviers. ${ }^{40}$ At the point in October 1431 when it was expected that Louviers would be taken by assault or would surrender, Philibert de Moulant, "maitre et visiteur de notre artillerie en France," ordered a quarry master to prepare and shape into rounds 100 balls from the quarries at Vernon at "vingt six poulces selon le kalibre sur ce lui bailla." These were to be delivered to the "cour de l'escurie" near the Seine at Rouen for transportation by river to the army around Louviers..$^{41}$ Eleven years later, masons from the vicomté of Alençon were paid five sous tournois per day for serving at the siege of Saint-Ceneri to make

35 For lists of equipment procured by John Parker, who was appointed the earl's master of ordnance, see TNA E 101/51/27/18 and E 101/51/30/4.

36 BNF manuscrit français $26046 / 62$.

37 BNF manuscrit français 26050/771.

38 See, for instance, a reward made by the English government in 1450, when Cherbourg was under threat, to a local priest who had spent eleven weeks locating and purchasing powder and saltpetre (TNA E 28/79/72).

39 Allmand, "L'artillerie de l'armée anglaise."

40 Paris, Archives Nationales [hereafter AN], K 63/13/15.

41 AN K 63/13/27. 
"pierres à bombardes, canons et culverins." 42 Add to this the ample examples of the hiring of carts for the transportation of guns and materials both between English-held places and from such places to sieges and back again, the presence of heavy guns being suggested by the use of 80 "grans beufs" for the movement of cannon to the siege of Le Mans in $1425 .{ }^{43}$ We even know that gunpowder was used to blow up fortifications where it was decided not to man them but to disable them for fear of their falling into the hands of the enemy. ${ }^{44}$

I could go on providing examples. On the face of it, then, we have the men, the machines and the wherewithal. But do we have the artillery revolution? The presence of gunpowder artillery at sieges was certainly no guarantee of success even in the period which Rogers suggests began to see the triumph of artillery. The English did manage to recapture Harfleur in 1440 but only by a combination of actions against the place itself and by mobile actions within the vicinity. They never managed to retake Dieppe despite use of gunpowder artillery. Furthermore, in some cases, most notably that of Louviers in 1430-31, the scale of investment required in order to enforce a surrender was immense.

If there is one overriding point which emerges from a study of the financial material it is the huge cost of gunpowder artillery. This is not simply limited to the production of the guns themselves but also to their repair, their transportation, the provision of powder, and their manning. The wage levels paid to all groups involved - cannoniers, carpenters, voicturiers - were much higher than military wages. Admittedly they were paid only for short periods, but, combined with the other costs, it seems to me to provide a considerable constraint on the use of gunpowder artillery by the English. There are other caveats. First, there was a limited supply of weaponry, especially when war was being conducted on several fronts at once. This may be a result of costs but there were other factors. There was the fragility of the artillery pieces themselves. In September 1427 attempts to recover Montargis were held up by the fact that many cannon had been broken by use in sieges in the campaigns into Maine and Anjou, and others had been dispersed to different places. ${ }^{45}$ Whilst it was possible to find some spares in Harfleur, they needed to be transported by boat to Paris and then overland to Montargis, not only a costly venture but a slow one. Furthermore, when guns were moved around, they needed to have substantial military escorts for fear of enemy capture. Guns were never in the place you needed them, and therefore they had less impact in emergency situations than in planned actions. Powder and stones could run out. Men could easily be moved, hardware could not.

I cannot claim to have exhausted all possible avenues of enquiry but my researches to date have suggested that there was little manufacture of guns within Normandy and that even repairs could be problematic. In October 1435

44 BNF nouvelles acquisitions françaises 1482/91 (concerning Vaudreuil, June 1430).

45 BNF manuscrit français 26050/771. 
the cannon in the castle of Rouen were "tournes a ruyne et empirance," but they could not be repaired on site because the forge did not have the right equipment. If they were removed for repair elsewhere, that would place the castle in danger (this was after all a very tense time for the English following the defection of the duke of Burgundy). The solution was to order the necessary equipment for the castle forge to be delivered to the cannonier, but alas we do not know the outcome of the case. ${ }^{46}$ The continuing provision of artillery pieces from England would suggest that supply within Normandy was not possible.

Access to other sources was dependent upon the fortunes of war. The French successes of 1429-30 cut off Normandy from Paris and what was left of its hinterland (although so far I have not found evidence of the use of material in Normandy from a Paris arsenal before this time anyway). To redress this situation, and also to accompany the young king who was crossing in person, a large army was despatched from England, landing in Calais in late April 1430. Much attention had been given to ordnance. John Hampton, master of the ordnance, not only had a huge train of 89 men but was also given over $£ 2,200$ to make purchases. On 16 April, the lieutenant of Harfleur and the treasurer of Calais were ordered to deliver guns and equipment to him. Hampton also purchased two large guns in Calais, weighing 6,780 pounds and 7,022 pounds, the smaller being named "the Henry," no doubt in deference to the king's presence. ${ }^{47}$ The suggestion is therefore that an arsenal was kept in Harfleur (the only place in Normandy to be "anglicised" as an intentional policy) and that Calais was a place of manufacture or of marketing. Alas, I have not been able to trace any further references to "the Henry," but perhaps it was one of the guns ordered later to be brought to the siege of Louviers. A further point to bear in mind is that the English position had been relatively secure until the reverse at Orleans. There had therefore been little incentive for major arsenals or centres of production to be developed in the duchy, hence the need not only for the greater provision from England and Calais for the royal expedition, but also in June 1431 the appointment of a "controlleur sur le fait des ordonnances de Normandie" with the specific charge of finding out what materials the English had in the duchy, where, and in what state. ${ }^{48}$

The defection of the duke of Burgundy and the loss of much of upper Normandy at the turn of 1435-36 was a disaster, not simply because it made overland communications between Calais and the rest of the English possessions impossible but also because it involved the loss of Harfleur where it appears that some kind of arsenal was kept. In May 1436 Paris was lost and Calais was itself threatened. Fear of further French penetration seems to have stimulated provision of (or at least movement of) guns to those places deemed to be most vulnerable, such as Rouen. ${ }^{49}$ The knock-on effect was the need to

46 BNF manuscrit français 26060/2643.

47 PPC, 4:31, 33; TNA E 101/52/22.

48 AN Collection Dom Lenoir [microfilm 104] 22, fol. 197.

49 BNF manuscrit français 26060/2696, 2768; 26062/3016. 
provide expeditionary forces with guns in England. The duke of York's anxiety over this point when he agreed to serve a second term in 1440 is seen in the terms he demanded, that he should be supplied with six great guns and four dozen stones for each of them "seying and consyderyng that in all Normandie is none or righte little neither for the stuff of garrison ner for the field." He also requested 26 gunners accompany his army. ${ }^{50}$ When the earl of Shrewsbury set sail for France in May 1442 a large quantity of "instruments and hablements" were prepared for his expedition "withouten the whiche our said cousins entent may not be executed nor putte in euce." Arrangements were also made for the "artillerers" to cross with the army. ${ }^{51}$ Similar arrangements were made for the expedition sent under the earl of Somerset in the following year.

These moves suggest that there was little spare artillery in what was left of Lancastrian Normandy and that what was there was being kept for defensive use. ${ }^{52}$ The truce of 1444 served as another disincentive to increase local provision. Although the duke of Suffolk later claimed that the cessation had been intended to serve as a period of rebuilding the English position towards the reopening of hostilities, this did not happen. When Charles was poised to invade the duchy in the early summer of 1449 , the duke of Somerset sent an urgent message to the parliament. He specifically mentioned that "there is no place in the kings obeissaunce there purveied nother in reparations, ordenaunce ne in eny maner artillerie," and that to remedy this "wold drawe to inestimable costs," costs which the local population could not sustain. ${ }^{53}$ The problem was not solved by the time Charles invaded the duchy. Even where there were guns there was a shortage of powder. ${ }^{54}$ Frantic efforts were made to send material across from England, not only for the defence of fortifications but also for use in the field against the French. In June 1450 the master of ordnance reported that he had supplied two serpentines, one culverin with nine chambers, 200 shots of lead, five great ribaudequins with 10 chambers, four greater ribaudequins with four chambers, as well as two carts and 30 carpenters, gunners, smiths and

50 Letters and Papers Illustrative of the Wars of the English in France during the Reign of Henry VI, King of England, ed. Joseph Stevenson, 2 vols. in 3 (London, 1861-64), vol. 2, part ii, p. 587. See also TNA E 404/57/263. He also requested 1,000 spear shafts, 4,000 bows, 12,000 sheaves of arrows and some bowstrings.

51 TNA E 404/58/92.

52 An interesting insight is provided by André de Laval's receipt for the equipment at Valognes which its English captain, Thomas Chiseval, handed over at the surrender in 1450. This included two serpentines made of brass (cuivre), one with three chambers, the other with two; also a brass culverin without a chamber; an iron culverin; two "roundels" of sulphur; a half roundel of "poudre"; a half roundel of saltpetre; nine barrels of "charbon a faire poudre" (BNF pièces originales 1668 de Laval 56).

53 Parliament Rolls of Medieval England 1272-1509, vol. 12 (1447-60), ed. Anne Curry and Rosemary Horrox (Woodbridge, 2005), pp. 56-57.

54 TNA E 28/79/72, payment to a priest of Cherbourg for his efforts, over the space of eleven weeks, to provide "gunnepowder, saltpetre and other divers stuff" at his own expense (December 1449). 
masons, along with powder for both guns and culverins. ${ }^{55}$ This suggests that the English intended to have guns with them at any engagement with Cade's rebels, and indeed guns may have been used at Formigny. The list suggests a reasonably up-to-date provision but in England rather than within Normandy, another example of the problems of having artillery in the right place at the right time.

All in all, therefore, the evidence from Lancastrian Normandy is not supportive of an artillery revolution on the part of the English. A further observation can be made from study of the names of the gunners taken over at least in the early expeditions, and also of the members of the retinue of the masters of the ordnance in Normandy. Although the masters were English on the whole (save for Philibert de Moulant serving 1425-31), most of the gunners serving under them were foreign. Henry V had taken a company of German gunners in 1415. German and Spanish names are seen in the retinues of the masters, as well as large numbers of French. ${ }^{56}$ The retinue always had a "clerc français," reflective of the linguistic needs not only within the retinue but also to assist the master in negotiating provision of guns, powder, etc. with marchant artillerers (evidenced in Rouen and Paris) and transport with local voicturiers, often arranged through the vicomtes who were all local men. In other words, the English in Normandy had developed little of their own expertise either in production or in manning gunpowder artillery. There was no real incentive to do so given the circumstances of the occupation. Not only did they hope for "integration" but also for much of the time their possessions were safe from attack, especially in Lower Normandy. The records show us that efforts were made to build anti-artillery defences such as boulevards, and to mount guns on towers and walls, but we must bear in mind that, with so many garrisoned places, it was extremely difficult to effect a consistent defence. The building of fortifications was as expensive, if not more so, than the provision of gunpowder artillery, and reliant on local taxation. It was therefore not surprising that in the Reconquest Mantes should surrender to Charles VII to avoid damage to the walls which the townspeople had spent money on. ${ }^{57}$

It is doubtful whether an artillery revolution could have helped the English in 1449. They had been taken by surprise. From the truce of Tours onwards, they had undertaken what we now call defence cuts, reducing the garrison establishment to no more than 2,500 men, thereby putting perhaps 2,000 out of employment, a figure increased by the abandonment of Maine in 1448. Many veterans, reluctant to accept their loss of employment, took to living off the land, causing relations with the local population to deteriorate. Various means were deployed to solve the problem. Soldiers of English birth were rounded up and frogmarched to Cherbourg and Barfleur to be shipped home. But can it be a coincidence that Charles was able to create his francs archers at the very

55 TNA E 28/80/65.

56 Allmand, “L'artillerie de l'armée anglaise," p. 77.

57 Anne Curry, "Towns at War: Norman Towns under English Rule, 1417-1450," in Towns and Townspeople in the Fifteenth Century, ed. John A. F. Thomson (Gloucester, 1988), pp. 149-50. 
point that the English were releasing large numbers of troops from their service? Remember the earlier point that many Frenchmen had joined the English garrisons. Shortly after the truce soldiers no longer needed in Lancastrian Normandy were detailed, as part of a bipartite agreement, to join the Dauphin in military action on the eastern frontier of France. The reforms follow the return of this force to Nancy, and were reminiscent of many aspects of English organization in Lancastrian Normandy, not simply in the use of archers alongside men-at-arms, the structures of command, and in the deployment of garrison troops for field service in the flexible English model.

Charles VII invaded Normandy with a huge army, certainly as large as that with which Henry V had conquered the duchy in 1417-19. On both occasions, there were few examples of actual bombardment as the significant factor. More commonly in the Reconquest, the French preparations for bombardment and assault, rather than actual bombardment, were enough to prompt surrender, much as they had been in Henry V's conquest. That does not deny that the guns used in 1449-50 were more powerful than those in 1417-19, as Rogers and others have shown. Furthermore, many surrenders were forced on the English by the local populations. That was certainly what happened at Rouen, which explains why there was no siege as there had been in 1418-19. Each place was picked off, one by one, but the fall of the major places led to a domino effect. As we have seen, the English had denuded their garrisons. There was little chance of raising a field army large enough to give battle within the duchy, unlike the situation in 1418-19 when Henry knew that the French had enough resources to attempt a relief. As we have seen, the troops which were finally sent from England were too few, too late, and with an imbalance between archers and men-at-arms. When forced to engage at Formigny, the English were very easily defeated, and with that defeat came the inevitable loss of the remaining places under English control.

Behind the English success in earlier decades, and the French success in 1449-50, was political will and also resources. Henry V had only achieved his conquest through the raising of, for England, exceptionally large armies. Behind these lay huge levies of taxation. His reign is one of the most heavily taxed of the whole of English history. In the 1420s it proved possible to sustain actions in Normandy and elsewhere in northern France through taxation levied in France itself. But once the French had rallied in 1429 and Charles had been crowned, it proved increasingly difficult for Henry VI's government to raise funds either in England or France. The political will diminished and the resource base with it, with the opposite trend occurring in France, although it took another twenty years for the "balance" between the two powers to be reversed. It also needed the English to lose their ally (France was too large a theatre to be controlled without internal assistance), and to reduce their manpower following a truce, and for Charles to increase both his political support (as for instance in his Breton alliance) and his manpower.

A military revolution needs a strong, well resourced government to produce it. Historians therefore need to look at the prerequisites rather than the effects 
of it. England had the prerequisites in the earlier part of the century, the French by the middle of it. In a sense this is Rogers' punctuated equilibrium but it is linked primarily to the balance of power between states and the relative standing of central control and resource provision. These condition the kinds of armies and weapons which states can deploy, not the other way around. The infantry revolution of the later Middle Ages was the product of monarchical power and resource (with the advantage lying with the English at first, and then the French). The artillery revolution was even more the product of such control and resource since, unlike provision of troops, it could not be provided by any other organisation than the state, or at least not at the level required to make an impact.

In no period can we understand military activity without understanding the political and resource context which produced and conditioned it. The real leap forward is therefore when states can support both an artillery revolution and an infantry revolution. This was beginning to happen in France in the mid fifteenth century, but it did not happen in England until well into the reign of Henry VIII, when it was linked to changes in the methods of taxation and revenue raising. Even so, it was not until there was permanent taxation, as opposed to one-off grants, on a large scale that there was the real development of standing armies of markedly larger sizes than those of the Middle Ages. This was a development of the seventeenth century in both countries. In terms of gunpowder, the breakthrough was the development of handguns. These required much less training "for life" than had been needed by late medieval archers or even men-at-arms, and therefore encouraged and made possible mass armies. But as mechanical instruments, they were also flawed, as were many of the larger pieces of the fourteenth and fifteenth centuries, and required a much larger number of men to fire them to have a real effect. Was this progress at all? 